\title{
Collective Bargaining and the Performance Rating in Italy
}

\author{
Barbara Grandi
}

\begin{abstract}
The big changes that have framed economies and societies all over Europe in the past decades have led to a changing role of the collective bargaining in the objectives it is pursuing[1]. This summary, presenting an overview on collective bargaining in Italy, is going to focus over the possibility for a collective agreement to determine the practices for better performance, the evaluation of such performances, as well as the connected monetary and/or non monetary recognition, in other words, the possibility for workers and their representatives to rate their own performance.
\end{abstract}

Keywords: Collective bargaining. Performance rating

\section{THE CHANGING ROLE OF COLLECTIVE REPRESENTATION OF WORKERS}

The big changes that have framed economies and societies all over Europe in the past decades have led to a changing role of the collective bargaining in the objectives it is pursuing ${ }^{1}$. This summary, presenting an overview on collective bargaining in Italy, is going to focus over the possibility for a collective agreement to determine the practices for better performance, the evaluation of such performances, as well as the connected monetary and/or non monetary recognition, in other words, the possibility for workers and their representatives to rate their own performance.

In Italian labor relations, the perspective which focuses over better performance and productivity is a relatively new one; Italian collective bargaining, typically centralized and State-connected, has traditionally had the aim to protect workers, rather than introducing them to improve productivity. The shift toward such a new scenario - involving workers in the search for solutions to productivity problems - is amongst the elements that have changed the social parties' approach to the capitalist economy, perhaps the most revolutionary of them all ${ }^{2}$.

First, I would like to specify that the phenomenon of "collective representation of workers" both in its contractual dimension (collective bargaining, just strictly meant) and in its political dimension (the role of trade unions in connection with national State policies) ${ }^{3}$, is here referred as a wide open legal category. This includes the concept of national collective bargaining and decentralized agreements, freedom of association, right to establish Trade Unions, joint bodies, tolerance/right to take collective action against employers' measures etc.

\footnotetext{
${ }^{1}$ On trends for European industrial relations see also C. DELL'ARINGA, T. TREU (1992) Nuove relazioni industriali per l'Italia in Europa, ed. Il mulino. For updating on workers' partecipation see http://www.worker-participation.eu consulted in 19th March 2014.

${ }^{2}$ About the contradictions amongst European policies, essentially framed by monetary targets and the national reforms on labour relations see S. DEAKIN, The sovereign debt crisis and European labour law, in Industrial Law Journal, Vol. 41, No. 3, September 2012 and cited readings.

${ }^{3}$ Some scholars refers to "negotiation" and "participation" as two possible dimension of workers' representation (G. BAGLIONI, 2008, L'accerchiamento. Perchè si riduce la tutela sindacale tradizionale, ed. Il Mulino, pp. 231-241)
} 
In time when the role of Trade Unions is politically under attack ${ }^{4}$, it is worthy to remind that Italian collective representation of workers too, finds its roots in the British Industrial revolution ${ }^{5}$, revolution which social effects have been spread all aver the world and still are manifesting themselves nowadays ${ }^{6}$; collective representation of workers, in this common worldwide spread - sense, have had the main aim of associating workers for protecting themselves from low pay, and from the full power of employers to manage the workers' life during the working time. Herefrom, we can better understand how the many historical approaches to collective representation of workers, as developed later on in the many European countries, have been shaped by several circumstances, particularly by the circumstance of the role as played by every national State.

The national social reform, at the beginning of 19th Century, led the Italian legislator, and many other European legislators indeed, to directly intervene for protecting workers against the risk of being abused by the employers' power. In other words the Italian Governamet too, intervened into the primitive bilateral relationship amongst workers and enterprises in order to make a new balance ${ }^{7}$, in order to save the personal dignity of those pressed in a relationship which is keeping them, as individuals, in the weaker position.

The content of collective rapresentation of workers coming here in point formost, is the collective representation for determining the remuneration; particularly, we are dealing with determination and bargaining over remuneration and productivity remuneration. We know that some national States like United Kingdom and Germany ${ }^{8}$ reached the adoption of a statutory determination of the minimum wage 9 . In Italy, instead, the minimum wage is still determined by the social parties, although the Governament uses to intervene via some variable sort of social dialog and puts its premission over the Agreements, according to rules that may changes through the years ${ }^{10}$ : the collective bargaining fixes the minimum wage, it fixes a remuneration which is going to be considered mandatory on any employer (the mandatory nature of the bargained determination is granted ex post by the judiciary system, because of a shared and consolidated interpretation of art. 36 of the Italian Constitution ${ }^{11}$ ).

This summary is not dealing with what is, or should it be, a decent/minimum wage, neither with how such a measure should be determined. Rather the paper deals with this kind of "new dogma" framing labour relations that is their role in allocating remuneration beyond the

\footnotetext{
4 The Movimento 5 Stelle, led by Italian comics Beppe Grillo, and achieving a great success at the 2013 24-25th Februry political elections, stressed its political campaign on abolishing the Unions essentially in their bureaucracy.

${ }^{5}$ Comparison between United Kingdom and Italy may turn to be fruitful, because in the most recent times too, not only at the origins, the debate over industrial relations takes its moves from Great Britain to develop in all the European Continent (this observation is by S. LEONARDI, Per una bibliografia ragionata sui temi del sindacato e delle relazioni industriali, Economia\&Lavoro, 3/2008).

${ }^{6}$ K. POLANY (1944) La grande trasformazione, ed. Einaudi (The great transformation).

${ }^{7}$ M.G. GAROFALO, Ludovico Barassi e il socialismo della cattedra, in Riv. Giur. Lav. Prev. Soc., 2001, $2003,394$.

${ }^{8}$ Germany is a country known to be deeply devoted to a centralized and statutory controlled collective bargaining (see M. FAIOLI, Oltre la continuità, la contrattazione collettiva decentrata nell'esperienza francese e tedesca, in RIDL, 2012, 3, 481)

9 R. BORTONE, I problemi della produttività e del salario in Italia, 2008, in http://www.robertabortone.it/htdocs/blog/?page_id=44, argues that such a statutory provision is being gravely experienced in time of economic crisis.

10 There can be partecipation, social dialgue, consultation, harmonization, information.

${ }^{11}$ Art. 36 of the Italian Constitution states that remuneration must be proportionate to the work done and sufficient for the worker and his family to live with dignity. Italian judges have interpreted such a principle as a measure to find in the national collective agreements.
} 
recognition and distribution of the minimum standards. This kind of new dogma does represent a shift from a collective bargaining which is only protective over the workers, towards a bargaining that is doing something for pushing productivity, innovation of economy and society, forward.

This summary moves from a theoric assumption (which is going to be debated elsewhere) that a decent wage or salary, to be granted as a fundamental right, is out of concern in Europe and all over the world, according to both general principles as declared in the European Charter of Fundamental rights and to the ILO Recommendations ${ }^{12}$. Such an assumption, in theoretical principle indeed, is to be considered as an achievement by the Unionism as a political and historical phenomenon, while it is going to be up to the political institutions, as in charge time by time, place by place, the decision over its implementation, its measure ${ }^{13}$, as well as over the instruments to establish it: every national State, in accordance with the civil society and the workers' representatives, should struggle (we are not dealing with an easy point) to find the best regulatory procedures and tools to establish, time by time, place by place, the minimum standards, in order to make that principle a reality for workers and citizens.

I take here as out of concern, nonetheless, that any variable part of the remuneration (connected to the merit of workers or to the productivity of the sector/enterprise) is distinguished from the minimum standards, although to be effectively connected to the national/minimum wage (either being the latter established statutorily or via collective bargaining having an erga-omnes effect). Given such a distinction, it follows that it is going to be at the higher/national level of determination that the substantial play for remuneration is taking floor, meaning that it is here that "the cake" (the existing production) is going to be shared; thereafter, the sharing of the resting part must be linked to that level in order to be identified. This assumption leads to consider that the way the society decides to share the cake, the tools it wants to use, the minimum standards and its components in any given sector, are strictly political matters.

It is true that collective labour relations is a topic particularly difficult to be analyzed from an academic point of view ${ }^{14}$; but if we leave to the social parties the determination of what is fundamental for a collective bargaining process to grant to workers, in term of a basic wage, on

\footnotetext{
12 The Charter of fundamental rights of the European Union sets several dispositions in order to grant minimum standards for workers: art. 27 Workers' right to information and consultation within the undertaking, art. 28 Right of collective bargaining and action, art. 29 Right of access to placement services, art. 30 Protection in the event of unjustified dismissal, art. 31, Fair and just working conditions, and all these norms, together, are meant to grant substantially and procedurally, minimum standards. Confirmed as an up-to-date standard by decision of the Governing Body of the ILO in 2001, Convention No. 102 has been ratified by 41 ILO Member States since its entry into force in 1952, and more ratifications are expected in the years to come, contains several statements aimed at granting workers' dignity. Moreover, see Protection of Wages Convention, 1949 (No. 95), Minimum Wage Fixing Convention, 1970 (No. 131), "Rules of the game, a brief introduction to the international labour standards, Revised Edition 2009". It seems that, the more a society is culturally advanced and informed, the more these standards are going to be assured by Institutions, rather than by the benevolence of Men. In 1998 The ILO made an effort to secure commitment of States to four core standards: freedom of association and the right to collective bargaining, elimination of all forms of forced labour and compulsory labour, abolition of child labour and elimination of employment and occupational discrimination.

${ }^{13}$ As well its eventual variations as related to the costs of living in a given society; circumstances emerging from the historical context, like the GDP (and GNP..) or the level of inflation etc. must be revealed when stating over the basic level of protection, otherwise the public intervention can go easily and unjustly towards determining stagflation.

${ }^{14}$ L. KINGSLEY, Is industrial relation an academic discipline? Journal of Industrial Relations Mar. 1974, vol. 16.
} 
one side, it becomes theoretically and academically easier, to define what is a variable production-connected remuneration on the other side, by simply referring to this as to the rest of the net production. In other words, what is over the level of the basic standard, given a positive economic outcome by the enterprise, is going to be treated as a variable (to be shared according to some specific, ex ante specified, criteria).

Collective bargaining regarding such a variable (meant as the potential outcomes over the minimum standards, emerging in the varying economic contexts differently, according to the different performance of enterprises and workers) can be a major tool in pushing the productivity forward and the welfare of society that can be "possibly" coming along. Without a normative attention to diversity in the outcomes of the many enterprises, there is a risk of "workers de-motivation"15 and breaks on productive/economic progresses, because both workers' performance and progress/innovation would be given no recognition.

Because of the uncertainty of the economy and economic outcomes, Unions aiming at granting a minimum wage as well as a productivity/variable wage, are directly responsible for the determination of it; in other words the Unions are responsible for the objectives they propose to achieve. Joint bodies ${ }^{16}$, associations with active participation of both employers and employes' representatives, meant to support and to finance the unemployment benefits, are examples of taking on responsibility in this perspective ${ }^{17}$.

What does it means that collective bargaining may play an important role in determining the performance rating, the practice for better performance, its assessment and then the monetary (but possibly also non monetary) recognition? What is collective bargaining over the rating of performance about?

It is important to conver what productivity evaluation means, because it is quite obvious, for any labour lawyer, that the simple concept of "productivity" is ambiguous: to ask a worker to be productive may easily turn into that worker being exploited.

Normatively speaking, it must be clearly stated by the working agreement - arguably by a collective agreement - what is essential for the worker to do, to seattle the time sheets in case of a dependent relationship; the worker's manner to perform, in case of dependence and semidependence; and finally the performance itself, meant as a result, in case of a self contractor. Given a certain remuneration to what is considered to be fundamental/essential in that relationship, the rest remaining is capable to be treated as a variable, meant as not essential, accessory. While the essential, or basic standard, with its own remuneration, need to be connected to a condition of dignity of workers, thus not negotiable, any reasonablessness is preventing from negotiating the rest of the performance/remuneration within a meritocratically oriented management. Such a negotiation, both in a dependent type of work or in an independent one, can be granted normatively, but it could deliver none remuneration if the result as supposed to be achieved will be not actually achieved.

\footnotetext{
15 A. H. MASLOW (1970) $2^{\circ}$ ed. Motivazione e Personalità, ed. Armando Armando, stressing attention on different level of motivation according to different level of need.

16 For an Italian definition see C. LAZZARI (2013) Gli organismi paritetici nel D.lgs 9 aprile 2008, Working paper Olympus 21/2013 http://olympus.uniurb.it

17 A. SPAZIANU e G. LEPORE (2009) I sistemi di gestione per la sicurezza e la salute dei lavoratori : il quadro di riferimento legislativo e la norma BS OHSAS 18001:2007 : manuale pratico per: datori di lavoro, valutatori e consulenti per la sicurezza, organismi di certificazione, enti bilaterali : aggiornato con il d.lgs. n. 106/2009 (decreto correttivo al T.U. sulla sicurezza nei luoghi di lavoro), Maggioli. EBER, Ente bilaterale Emilia Romagna (2002) Monitoraggio apprendistato : il ruolo degli enti bilaterali nella formazione per gli apprendisti.
} 
Now, while determining what is essential (and what is not essential) we are facing with a preliminary, philosophical issue. If we do not offer a reply to this, the following dissertation about productivity is going to develop ambiguously.

The philosophical issue is about the "potential choice" of the worker: if we accept the idea that the choice of the worker is never a free choice, that he is forced always by the need to pursue the dignity of himself and the welfare of his family, then any discourse over productivity and merit may sound as putting a shadow over this preliminary and uncomfortable truth.

On the other side, when hosting the idea that the worker does have a choice, instead, we open the door to a more complex but challenging and sensible discourse over the different type of participation of workers to the economic and social growth broadly speaking.

The second perspective appears to be theoretically preferable for being more lively and active, it is more reliable because of its connection to real life indeed.

It is preferable also for the reason that any economic and social context, as well as any specific personal or objective circumstances, can be better observed from an external, rather than internal, point of view. Freedom of choice is something like an oversight over the (usually bilateral) employment relationship.

Also some others, typically legal, arguments, may come to support this view. For example, from a Trade Unions' perspective, European collective bargaining is assisting to an increasing importance as just given to decentralized agreementsl, also departing from the national bargaining level ${ }^{18}$, and this fact attest some consensus over the need to differentiate treatments according to a variable productivity ${ }^{19}$.

Furthermore, from a traditional civil law view, the contractual nature of the working relationship has never been completely denied by the social labor law studies ${ }^{20}$, and this fact is something confirming an active role played by the workers, notwithstanding the intervention of national States and the tendency to speak in term of a status position which highlights the protection of workers' vulnerability.

\section{ITALIAN COLLECTIVE BARGAINING ON PRODUCTIVITY}

Italian labour relations focused their attention over productivity particularly since the 2009 Basic Agreement, but the Unions' strategy to invest over the variable part of the economic outcomes was adopted already with the 1993 Protocol (Accordo Interconfederale 1993, July, the 23rd), signed at a national level by the three main Unions (CGIL, CISL, UIL) in agreement with the Government.

The 1993 Protocol was aimed at fighting inflation and matching the European standards to keep the public debt under a fixed percentage. That Agreement provided a contractual setting giving space to the local/work place collective bargaining, without denying the major impact of national bargaining on income distribution. Local bargaining was given the jurisdiction over

\footnotetext{
18Rapporto 2008-2009 CNEL, Le Relazioni Sindacali in Europa, 24 luglio 2010

${ }^{19}$ G. BAGLIONI 2008, cited above, argued, furthermore, over benefits possibly coming along with an autonomous level of bargaining.

20 S. DEAKIN \& G. MORRIS, Labour law, 2005, 121; L. MENGONI (2004), Il contratto di lavoro, (a cura di M. Napoli), Vita e Pensiero (92-93).
} 
topics and tools not already ruled at national level, and such a connected remuneration should have been strictly connected to the realization of programs - as previously agreed by the social parties - and having the objective to improve production, quality of the outcomes, or other competitive elements which the enterprises may use, including productivity margins and results linked to the economic trend of the enterprise.

Therefore, the idea in 1993 was to link a part of the outcomes, as variable in each local reality, to the achievement of some goals by one or more enterprises working together; there was no specification over the goals to be achieved, no specifications about whether the goals set should be individually or collectively achieved. This was left to national and decentralized collective bargaining. The State substantially submitted the Agreement by mean of a reduction in taxes which are to be paid regularly on remuneration: the taxes reduction concerns the productivity remuneration only.

The 2009 Basic Agreement (Accordo Interconfederale signed on 2009, January, the 21st) was confirming this kind of normative setting. It was not signed by all the unions; CGIL decided not to stay into the alliance, because of the denounced tendency of it to press too much toward a productive and flexible scenario rather then a protected once. The Italian Government submitted, and took the commitment to treat the variable part of the remuneration with lower fiscal pressure.

The 2009 Agreement, particularly, gave to the national contract the power to defend the salary against inflation and gave to the local bargaining the power to distribute the variable outcomes as connected to the productivity of the enterprise ${ }^{21}$, not differently from what was already stated in the 1993 Protocol. The social parties obtained to adopt a criteria for updating inflation which was much more akine to the "real economy", if compared with the ruling dated $1993^{22}$.

The 2009 Basic Agreement stated once again that decentralized contracts should have jurisdiction over what not ruled yet by the national contract.

Differently from what submitted in 1993, nevertheless, the new pact provided for the local bargaining the possibility to depart from the national statements, but only, precisely, in case of economic crisis or in order to achieve occupational goals.

Another important achievement was the introduction of a sort of a "warranty clause". This provided applicability of the national standard for productivity whereas the decentralized bargaining would not be present. This tool was not furtherly specified in details at this basic level of consensus, while a later Basic Agreement dated 2009, April the 15th (Accordo Interconfederale 15 Aprile 2009, not signed by CGIL, aimed at giving application to the January the 21st Agreement) furtherly specified that national collective bargaining should state over a measure for productivity remuneration to grant in case the decentralized bargaining would have failed to provide for it (art. 4) $)^{23}$.

\footnotetext{
${ }^{21}$ C. DELL'ARINGA, Le nuove relazioni industriali, la partecipazione e la sicurezza sul lavoro, Dir. Rel. Ind.2012, 21

22 The new index (IPCA) is the index for prices as comparable and harmonized in the European context.

${ }^{23}$ Art. 4 regards the so called "elemento di garanzia retributiva"; CGIL did not agree, by saying that it is formulated in such a way to be substantially not assuring any minimum wage at national level to those not covered by local bargaining (http://www.cgil.it/dettagliodocumento.aspx?ID=11623 consulted on 2013, March, the 7th ). See also art. 4 bis as signed by Federmeccanica, Assital, Fim-Cisl, Uilm-Uil
} 
Actually, what the 2009 basic negotiations did not achieve was a "territorial" level of bargaining to cover those small enterprises not yet capable to have collective bargaining inside of their own premises. Furthermore, some scholars seems to suggest that there was not enough clarity as if the real power of remunerations (control over inflation) should have been connected to minimum/national wages only, rather than to productive/decentralized remunerations too ${ }^{24}$.

Both the Basic Agreements of 1993 and 2009 are applicable to private and public sector as well.

In this respect, it must be recalled that 1993 is the date signing also the departure from a specific ruling for the public service in Italy, except for few categories (see D.lgs n. 29/1993): since that time, public and private emplyoment are ruled by the same contractual norms. Thereafter we can observe a convergence amongst players of the public sphere (Parliament, Governament and Trade Unions) with those playing in the private sector (private interests represented within the public institutions); such a converging trend has been confirmed in the later agreements and it is amongst the more, fundative, debated topics in Italian politics. Such a convergence is attesting an overall process of "contested liberalization" in Italy, begun in the early 90 's ${ }^{25}$.

New art. 40 of D.lgs $165 / 2001^{26}$ as amended in 2009, ruling the collective bargaining for dependent workers in the public sector, although in a normative trend ${ }^{27}$ aiming at reducing the Union's power inside the public administrations in favor of both statutory law and public managers' prerogatives, does provide expressly a remaining jurisdiction for the Unions on performance rating. The 2013 DPMC January 22nd, an act by the Minister of Labour, declared that the provided measure to support prodictivity (having the form of a reduction on taxes) only applies to the private sector.

The 2009 Agreements rised some extremely important cases regarding decentralized bargaining in Italy. The main one is the Fiat case in 2010, which exposed to the general public attention the matter over relations between national and local bargaining (matter perceived in the form of the typical struggle of the market reasons against the workers' rights): what happened is that the Fiat management decided to renew the working conditions for the production of some new car models, by negotiating very circumstantially the production system and employment management in plants like that of Pomigliano d'Arco, Grugliasco, Mirafiori. For example, it negotiated the prevention of some typical forms of absenteeism rooted in the social culture of the South of Italy (Pomigliano D'Arco) with the introduction of severe penalties regarding false attestations of absence in place of real illness. The local contracts departed from the national collective agreement, therefore facing a hard opposition by the Unions, and by the FIOM-CGIL Union specifically: this latter decided not to sign the local agreement (considering it in contrast with national standards) and such a tight position lead the Fiat management to take distance from the national contract itself.

\footnotetext{
${ }^{24}$ M. RICCI (2009), L'accordo quadro e l'accordo interconfederale del 2009: contenuti, criticità e modelli di relazioni industriali, Riv. it. dir. lav. 2009, 03, 353.

25 L. ZOPPOLI, Contratti collettivi e circuiti della rappresentanza, La riforma Brunetta due anni dopo, in Diritti, Lavori, Mercati, $1 / 2011,24$

26 D.lgs n. $165 / 2001$ is the main law ruling the public servant employment relations.

27 See Legge n. 150/2009 the so called Legge Brunetta
} 
Several claims have been brought by the FIOM-CGIL associated workers before employment tribunals, in order to achieve a declaration of existence of their Union members rights based on the argument that the local agreement is in contrast with the national collective contract in force ${ }^{28}$.

The later Basic Agreement (again in the form of a trilateral understanding, included the Government) is dated 2011, June the 28th (Accordo Interconfederale 28 Giugno 2011) and has had the important impact to re-unite the three main Unions, CGIL included, after the chaotic experience of the Fiat case; essentially the settlement has been achieved through a new regulation over the matter of Unions' representativeness and their rights. There has been a great level of disappointment over the work done by the Unions in Italy; there was, and there is still, an idea that they are incapable of really representing the majority of workers, both because of the productive areas not covered by collective bargaining on one side, and the distance between Unions and their associated members on the other side. Herefrom comes the major importance of coping with the "representativeness knot". As for productivity, the new Pact confirmed the policy according to which decentralized agreements can rule over matters as just delegated by national contracts; as for decentralized contracts' legal effects, these are supposed to be binding over all the workers once approved by the majority, as sorted out in the premises which are involved in the bargaining. The decentralized collective contract can depart from the national contract, but remaining within the limits and procedures as normally present by the former, as it was in the past. Decentralized agreement, newely, can further derogate on national standards for experimental phases, in need to manage with circumstances of economic crisis, significant investments, to favor economic development and occupational protection; in such cases the local bargaining can cover matters of human resource management, meant as management of tasks and job-positions, timeshifts and so on. The autonomy of the local bargaining seems to be broader than in past; there is no mention of any economic tools, while the Basic Agreement asked generically for a governmental intervention to encourage the local bargaining aimed at "allocating remunerations connected to productivity, income, quality, efficiency, efficacy and any other tool as capable to improve competition and economic results".

The 2011 Agreement came just before an intervention of the State, having hardly destabilized the public opinion (Legge n. 138/2011 art. 8) by a statement according to which decentralized collective agreements could opt for departing from also statutory law, so far until European laws and constitutional principles were respected. Such a statement constituted a major news for Italian collective representation of workers, given that since the origins of collective association recognition, only few exceptional cases were allowing collective bargaining to formally depart from statutory law ${ }^{29}$. Many commentators have declared the law to be in contrast with the basic structure and fundamentals of Italian Unionism but surely it represented a strong intervention by the Government ${ }^{30}$ aimed at giving to local bargaining a decisive impact on the human resource management 31 : it represented an authoritative intervention aimed to directly rule industrial relations at local level, giving them efficacy and

\footnotetext{
28 See particularly Modena and Torino employment Tribunals decisions in 2010 concerning the applicability of 2008 and 2009 collective agreement http://www.pietroichino.it/?p=14214. It is waited a decision by the Constitutional Court regarding Unions' representatives rights.

29 That is the case for collective bargaining in the public sector as for wages (see D.lgs 165/2001 art.2)

30 The Basic Agreement is dated June 28th, the law is dated September 14th.

${ }^{31}$ A. PERULLI e V. SPEZIALE (2011), L'articolo 8 della legge 14 settembre 2011, n. 148 e la "rivoluzione di Agosto" del Diritto del lavoro, in WP C.S.D.L.E. “Massimo D’Antona”, n. 132/2011; , sul punto p. 6 ss.
} 
direct legal effect ${ }^{32}$, thus establishing a prosecution of a policy that dates itself back in the 2001 Libro Bianco ${ }^{33}$. The 2011 law took the view that decentralized contracts might rule over information technologies and distant controls, tasks of the workers, classification of workers and job positions, fixed term contracts and other flexible contracts like triangular relationship, time-sheets, hiring processes, discipline procedures, economic remedies against dismissal, expect for dismissal due to a discrimination. All of these aspects might play a major part in the ruling over productivity.

CGIL, on its side, expressed the critic of being this law an impediment along the way for national collective bargaining coordination: while the Basic Agreement was granting a coordination between the national contract and the local once, the new statutory norm was concerned as denying any coordinating role to be played by the national contract ${ }^{34}$. After a relatively successful strike, announced by the CGIL leaders in September 2011, an important understatement for the application of the Agreement was achieved by the three main Unions thereafter re-united: the Statement signed on September the 21st declared that "Confindustria, CGIL, CISL, UIL agree that industrial relations are a matter for Unions (only) in their own autonomy; by consequence, the parties agree that they will apply the June 28th Agreement at all levels of bargaining". This understanding clearly represents a substantial frustration of the law in point (recalled as "art. 8"): it is true that the law can prevail over a contract, but so far until the law is willing to rule over the autonomy of Trade Unions, it turns to be useless without the Unions' consensus.

From an outstanding point of view, the issue is open still for autonomous Unions and worker's representatives (those standing outside the basic understatement as nationally agreed) willing to play out from the national bargaining system.

Of a paramount interest for gaining consensus about productivity management amongst Unions has been, then, the Basic Agreement in 2012 (Accordo Interconfederale, dated November the 16th)

This Agreement has had the form of a strong invitation to the Government and Parliament ${ }^{35}$ to intervene on the process for structural reforms aimed at achieving an economic reprise in the long run, by means of a major support to collective bargaining managing productivity; collective bargaining appears to be a coordinated tool for social relations between central and decentralized Unions, and it expressly recognizes agreement in the work place (decentralized agreements) as a useful tool to gain foreign investment, to avoid exportation of Italian productions, to realize an overall objective of protecting occupation via an economic development at local level.

Relevantly for the Italian traditional legal system, this Agreement is asking for a new ruling on "equivalent tasks" directly by collective bargaining rather than by law "equivalenza delle mansioni" ex art. 2103 Italian civ. cod.), as well as a new ruling on working time and information technologies.

32 A. GARILLI (2012), L’art. 8 della legge n. 148/2011 nel sistema delle relazioni sindacali, WP C.S.D.L.E. “Massimo D'Antona”.IT $-139 / 2012$

332001 Libro Bianco is a governament statement over labour policies, and it was inspired by the main contribution of Prof. Marco Biagi.

34 Read more on http://it.ibtimes.com/articles/24244/20110911/art-8-del-d-l-138-2011-cosa-cambia-per-i-lavoratori-leragioni-della-cgil-camusso-manovra-ferragosto.htm\#ixzz2JB2HSxTS

35 Notwithstanding the limits deriving by Legge n. 114/2012, ratifying the European pact for the public balance stability. 
The Agreement, submitted again without the support of CGIL ${ }^{36}$, is evidently a continuation of the mentioned policy making started in the late Nineties, tending to provide an active participation of workers in the progress to increase incomes and it's been supported by the Government with a provision of around 2 billions euros financing the reduction in tax payment on those incomes as just connected to productivity results ${ }^{37}$. But then again, the Trade Unions unification has been re-stated, occasionally for the Basic Agreement dated 2013 April the 24th. This late Agreement in 2013 is signed to give application to the DPCM already mentioned and regarding the State support to the productivity remunerations and presents a model for a territorial bargaining over productivity: the social parties propose a model which destiny is to be overruled by any eventual agreement in the workplace and precise that employers will be given the State benefit as provided by the DPCM (reduction in taxes) "on those performances others than those offered to comply with normal work-time"38.

The resulting normative system on productivity, as just framed by DPCM, and the 2013 Agreement 24th, is rather centered on a meaning of productivity remuneration which seems to be strictly linked to the measure of the working time. There is the risk of linking the meaning of productivity to only a matter of quantity (time spent on the working place) rather then to also really innovating procedures and contributions that are not strictly connected to the hours spent on working. Nevertheless, it does note exclude the consideration of linking the State support to other kind of performance rating: for example it is considered as a productive type of work that as offered as a mission ${ }^{39}$ or "any changing of the working time" (art. 4) that is a consideration going beyond the mere "increasing" of the working time. The Ministerial Act (DPCM) then referes to:

1. New definitions of the working time;

2. Flexible distribution of holidays:

3. Measure tending to use technologies in order to comply with fundamental rights;

4. Flexibility in job position and tasks, also via technologies innovations ${ }^{40}$.

\section{PROS AND CONTRAS OF DEALING PERFORMANCE RATING BY COLLECTIVE BARGAINING}

I have just recalled how the matter of productivity is in Italy a complicated mixture of rules managed at different levels, significantly also by the statutory law.

Generally speaking, collective bargaining appears to be desirable as a source of law based on searching and achieving agreement amongst parties with divergent interests, "by means of a mutual availability to build with patient intelligence, even with experiments an errors, successive evaluations an adjustments, temporary solutions but a with normative and binding effect" 41 . This means that collective bargaining is a kind of flexible, soft law that is particularly adequate to fit society in time of changes and complex economic realities, like the one we are living in.

\footnotetext{
36 http://www.ilsole24ore.com/art/notizie/2012-11-16/accordo-produttivita-camusso-scrive-122949.shtml; http://www.ilfattoquotidiano.it/2012/11/20/accordo-sulla-produttivita-modello-marchionne-isola-cgil/420117/ 37 See DPCM January the 22nd.

38 In Italian: "erogate a fronte di prestazioni lavorative diverse da quelle rese in osservanza degli orari di lavoro applicati in azienda".

39 The State benefit is expressly recognized in the 2013 Agreement for workers sent in mission; it is arguable that the Agreement is here referring to intermediated type of employment contracts.

40 Circolare Minister of Labour n. 15/2013 dated April 2013 is giving some more indexes to allocate productivity remunerations wich seems to be not limited into a bilateral relation "more work-more productivity", and provides for a control over the correct application of the provided measures.

${ }^{41}$ I. REGALIA (2003), cited above, 428
} 
The first argument "pro" collective agreements dealing with performances might be the positive experience of some joint bodies, as forms of employers' and workers' representation slightly different from a mere collective bargaining, embracing social dialogue in a more articulated form. These have reached some major results in the fields of professional training and health and security in the work places ${ }^{42}$; these are fields very much near, as for their complexity involving many competences and level of management, to that of performance rating.

Perhaps the main obstacle facing the use of joint bodies (which are operating on the base of a collective agreement anyhow) may come from the unionism itself, whenever it considers joining the management like putting at risk its own autonomy.

The second argument is of an economic nature, and it concerns the idea that collective bargaining should be used whenever it is economically proficient to share information: the more the negotiation is asking for disclosure, the more it is preventing from taking decisions based on incorrect factual assumption ${ }^{43}$. The matter of "shadowed attitudes", which are by nature not economically efficient, is going along with opportunism.

The third argument is the authentic democratic nature of any process involving directly the workers in the measuring of their own performance. Workers given voice at saying what and how should be better to rate when workers themselves (as well as the entire enterprise) are watched with the lenses of productivity, and can grant a directly informed, a professionally instructed, and a directly interested point of view. It follows that, as long as we consider democracy like a good method to rule a social context, then collective bargaining on performance rating should also be valued.

According to some studies ${ }^{44}$, only a personal incentive may stimulate a rational person belonging to a group to act in a "group-oriented" manner, that means that only a benefit strictly reserved to the members of the group is capable to motivate their real participation and contribution $^{45}$; this argument support the idea of a democratic decisional procedure, and might be used once considered all the individuals working in an enterprise to be a group indeed.

Moreover on democracy, I can recall sociologists' theories that are describing human society as a movement which is naturally forcing against changes caused by the supremacy of the market economy ${ }^{46}$ : resistance is a word that expresses humanity, and the society as a group of human beings is expressing resistance against the pressure of economics whenever representing an abuse or a threat to human dignity. This argument embraces the philosophic approach according to which it is the sense of rejection and fighting against humiliation that moves history rather then the sense of attraction towards the better ${ }^{47}$.

\footnotetext{
${ }^{42}$ C. LAZZARI (2013), Gli organismi paritetici nel decreto legislativo 9 aprile 2008 n. 81, in Working papers 0lympus 21/2013; A. SPAZIANU e G. LEPORE (2009) I sistemi di gestione per la sicurezza e la salute dei lavoratori : il quadro di riferimento legislativo e la norma BS OHSAS 18001:2007 : manuale pratico per: datori di lavoro, valutatori e consulenti per la sicurezza, organismi di certificazione, enti bilaterali, Maggioli. EBER, Ente bilaterale Emilia Romagna (2002) Monitoraggio apprendistato : il ruolo degli enti bilaterali nella formazione per gli apprendisti.

43 R. B. FREEMAN (2006) Searching for the EU social dialogue model, NBER Working Paper No 12306 Cambridge MA.

${ }^{44}$ M. OLSON, 1990 The Logic of Collective Action: Public Goods and the Theory of Groups (trad it. Logica dell'azione collettiva, Feltrinelli)

45 Such a theory does imply the consideration that "rational" members of a group can act to achieve private goods but not pubblic goods as well.

46 K. POLANY (1974) cited above

47 Z.BAUMAN, Voglia di comunità, Laterza, 2001, 17
} 
An argument as just connected to this late one, is the consideration that the matter of performance management could be dealt with direct democracy procedures - not mediated by Union's representative's, not expressed by act of a workers' delegate, but by act of the workers themselves: many aspects of the performance rating could be decided indeed on a direct basis, rather than on a delegated one.

The modern information technologies (IT) would deliver the tools to such a direct kind of workers' participations, insofar as the choice would imply an "aut-aut decision" 48 . Workers and employers representative (delegated) could keep the role to manage the whole decisional process formally, and to supervise it from an institutional point of view (preventing, adjusting and mediating on procedural faults, keeping the archives, technical support etc.). Here below are some examples of the aut-aut options that a direct negotiation concerning productivity rating could set.

\begin{tabular}{|c|c|c|}
\hline Object of the productivity rating & $\begin{array}{c}\text { compensation/remuneration of } \\
\text { productivity }\end{array}$ & contractual options \\
\hline $\begin{array}{c}\text { Individual productivity (by tasks, } \\
\text { projects, items, etc.) }\end{array}$ & free hours (time off) & $\begin{array}{c}\text { to whom } \\
\text { (personal scope of the clause) }\end{array}$ \\
\hline $\begin{array}{c}\text { Team/enterprise productivity (by } \\
\text { tasks, projects, items, etc.) }\end{array}$ & $\begin{array}{c}\text { percentage on output and services } \\
\text { delivered }\end{array}$ & $\begin{array}{c}\text { for how long } \\
\text { (temporal scope of the clause) }\end{array}$ \\
\hline Leadership & Leadership & $\begin{array}{c}\text { adjustments with past ruling } \\
\text { (opting between old and new } \\
\text { clauses) }\end{array}$ \\
\hline Innovation & social services & $\begin{array}{c}\text { derogability of the clause } \\
\text { (possibility for opting out) }\end{array}$ \\
\hline
\end{tabular}

Scholars recall that the Ford's model of production and the post-Ford's model imply two opposite relations between the individual growth and the control over production ${ }^{49}$ : Ford's model was pressing the individual power of knowledge and control over the production but it was including the person inside the big industry, thus promoting the feeling of belonging to a community, whereas the post Ford's model is doing the opposite. The post Ford's model is apparently doing the reverse, by letting the person growing in knowledge as well as in control over her performance, but then leave her alone in the "open society" and in a network of soft laws.

If this is true, inevitably the perspective of workers' participation in the management and organization of work is becoming a necessity in our nowadays society. But for tons of inch just used to underline, on the other side of the river, that the employment relationship is, in its nature, conflictual, which is comprehensible as well; participation of social parties (which is also based on a Constitutional principle in Italy, art. 46) is not excluding the conflict. There is no need for an aut-aut option here: insofar the conflict would rise, there information procedures might come to support.

As for the "contra", the major argument coming in mind against the idea of collective bargaining as a source for ruling performance, is its cost, compared to the cost of a unidirectional management by the employer, which is the regular path for any employer in a liberal economy. 
Any shared procedure implying confrontation amongst potentially contrasting interests does require much effort in terms of time spent and procedural tools to buy or to use (for delivering information, spaces for discussion and express opinions, options, choices).

IT is offering a major help to cope with such costs: it offer shared platforms for discussing and voting directly also. The experience of the so many social network that in these last decade are reversing their echoes over the public opinion and political institutions might be taken seriously also by the Unions, which are about to play an active role at the local level as well on higher levels of bargaining ${ }^{50}$ : the cost of technology service is potentially well underneath its potential benefits, not only in time of conflicting situations, but specifically because of the voluntary and competent participation of the interested employees in the day by day living of the enterprises.

A relevant experience for the cut on costs of democracy, is the so called "liquid feedback as a program for interactive democracy" 51 developed by the Public Software Group in Berlin ${ }^{52}$, Germany, whose basic idea sounds like this: "a voter can delegate his vote to a trustee (technically a transitive proxy). The vote can be further delegated to the proxy's proxy thus building a network of trust. All delegations can be done, altered and revoked by topic. I myself vote in environmental questions, Anne represents me in foreign affairs, Mike represents me in all other areas but I can change my mind at any time. Anyone can select his own way ranging from pure democracy on the one hand to representative democracy on the other. Basically one participates in what one is interested in but for all other areas gives their vote to somebody acting in their interest. Obviously one may make a bad choice once in a while but they can change their mind at any time"53.

A mixture of direct democracy and directly delegated democracy would allow, with a cost that is supposed to be rather lower then any kind of material ballot, a participation to anyone who directly cares, a delegation to those who prefers to delegate, as well as a passive role in case the single worker just don't care in giving his opinion.

The system was engaged by the so called Pirate Party 54 in Germany, in 2009, willing to perpetuate the chances for each and every party member to participate in both the development of ideas and decisions.

It is acknowledged by the developers of the system that the operation of it in the context of economy and corporations requires the understanding that in such a context democracy is not the matrix of the interested social relationship: it is not going to be easy to give voice to employees whose interest is "generally" in contrast with the interest of the employer/corporation. In other words, the main problem with this approach is the balance between reliability of IT procedures expressing consensus and dissenting opinions on one side, and the ultimate right of the employer to decide and to manage his business on the other side. In order to grant, specifically, the genuine nature of social dialog within a company, it must be decided who is going to control the security and maintenance of the IT software.

\footnotetext{
${ }^{50} \mathrm{http}: / /$ strongerunions.org/2013/03/02/how-are-union-members-using-the-internet/

51 http://liquidfeedback.org/

52 Public Software Group; the software is basically free to everybody; other similar sofwares are Adhocracy and CrowdVote. For a short reading: http://daily.wired.it/news/internet/2012/09/11/democrazia-diretta-elettronica-183456.html

${ }^{53} \mathrm{http}: / /$ liquidfeedback.org/mission/

54 http://it.wikipedia.org/wiki/Partito Pirata
} 
From a progressive perspective, nevertheless, "visionary boards are interested in unleashing the creativity of their employees" 55, employers looking toward society as a changing scenario, employers staying open in remaining on the market in a stable and sane position should constantly look at the future in all its complexities, and the opinion of workers is included with priority in this complex vision.

\section{CONCLUSIONS: THE UTILITY OF A COMPARATIVE EXPERIMENTATION}

I propose a conclusion by passing through two considerations. First, the complexities of the Italian labour relation system are exposing the latter to a critic of non-efficacy ${ }^{56}$. It has been observed that labour relations can establish an efficient regulation when they, openly and largely, let the State and its agencies to intervene (the Scandinavian model is an example of this pattern), while reversely, a system like that operating in Canada or in the USA, having a tradition of bargaining connected to the market logics, rather than to State policies ${ }^{57}$, can reach an efficient regulation hereby. Italy, like the United Kingdom, is some in the middle, and faces the problems connected to such a compromise.

Second, the experience of the world economic crisis, so far, has shown that social dialogue can help to preserve or even improve competitiveness ("Member States with strong social dialogue mechanisms have weathered the storm best. National cross-industry negotiations have developed in response to the crisis in a number of countries with little tradition of such dialogue"58).

It follows that some experimentation are inevitably essential to adopt a collective bargaining over the performance rating, both in the public and in the private sector; a comparison between some more "American oriented" collective bargaining and some more "State centered bargaining", along with comparable companies from the USA and, Sweden for examples, would be highly beneficial.

Nothing is preventing from the adoption of a matrix for a collective consultation/bargaining/deliberation over the performance evaluation as far as it is proved that its effect has added something to the value of the company also in term of competitiveness ${ }^{59}$. The scenario of a real full democratic process to share the outcomes of business is still representing an utopia but here again the utopia is moving towards a better regulation insofar the whole system is gaining from it a real benefit as for the wellness of society: perhaps, the Eden is the far point of arrival, and already the point for the next departure, insofar we call good intention both trains to.

\footnotetext{
${ }^{55}$ A. H. MASLOW (1970) $2^{\circ}$ ed. Motivazione e personalità, remind us the importance of an olistic vision of any evolving society, where also higher ambitions of people (not only the instinctual once) are determining the behaviours, and further more where ambitions and desires are continuously changing because of the so called circle of satisfaction.

${ }^{56}$ C. DELL'ARINGA, T. TREU (1992) Nuove relazioni industriali per l'Italia in Europa, ed. Il mulino, 14 registered that Italian productivity rate was amongst the lowest in Europe.

${ }^{57}$ C. DELL'ARINGA, T. TREU cit. above; according to these countries experiences, not only the part of the salary which has been connected to productivity is relying on the economic performance, but also the rest of is under negotiation.

${ }^{58}$ Social Europe Guide 2012, Volume 2, European Commission (http://ec.europa.eu/social/BlobServlet?docId=7384\&langId=en)

${ }^{59}$ S. SCIARRA, 2010 Experiments in the Open Method of Coordination. Measuring the impact of EU employment policies, RIDL, 2011.
} 